\title{
Trade Unions in Nigeria and the Challenge of Internal Democracy
}

\author{
Toyin Adefolaju, (Ph.D) \\ Department Of Sociology, \\ Ekiti State University, Ado-Ekiti, Nigeria. \\ E-Mail: toyinremi2003@yahoo.com \\ Phone: $08038554307,08026067755$.
}

Doi:10.5901/mjss.2013.v4n6p97

\begin{abstract}
Trade Unions emerged from the efforts of workers to seek improvement on existing working conditions through collective actions. They function to provide social, economic, political and psychological benefits for their members as well as the platform for participation in managerial functions in the industry. Today's unions are no more mere bargaining agents or lobbyists but rather transformed into a social movement through which the working class has promoted mass democracy. In the face of persistent agitation for participatory democracy in the larger polity, this paper examines the level of adherence to the tenets of democracy in the internal workings of five trade unions across south west Nigeria. A total of six hundred and forty workers in wage employment were selected for this study, using a multi-stage ramdom samplying technique. In-depth interviews were held to compliment the use of the questionaire administered. The research reviewed some literature and is hedged on the pluralist perspective. The findings revealed that these unions are yet to imbibe the tenets of democracy in their internal administration as, for example, female participation in their activities is only about 23 percent. The study therefore recommends appropriate measures to ameliorate the situation.
\end{abstract}

Keywords: Trade unions, organisations, democracy, equality, management, workers

\section{Introduction}

Trade unions are generally organized groupings of workers that relate with employers on various issues related to the conditions of employment of their members. They arose as a consequence of the industrial revolution which led to the development of industrial capitalism. The revolution had given birth to accelerated resource accumulation and the consequent growth of large-scale enterprises. It therefore brought together thousands of employees working together, leading eventually to the creation of management problems for the entrepreneurs. Essentially the industrial revolution impacted on Britain in the following ways:

- the breakdown in the domestic system of manufacturing;

- $\quad$ the growth and development of entrepreneurial activities;

- $\quad$ the beginning of labour relations between the employer and employees;

- $\quad$ the congregation of workers at the workplace, which then facilitated the need for discussing their welfare; and

- the general view of labour as commodity with a price. This gave workers the awareness that they have something, which they can use for bargaining with a view to making ways for their existence (Zysman and Schwartz, 1998).

Trade union action is therefore, couched on a class struggle between the capitalists and workers having opposing interests. While the capitalists attempt to increase their profits by cutting down wages and increasing the hours or intensity of labour, the workers attempt to increase their wages and to shorten their hours of work. Trade unions therefore emerged from the efforts of workers to seek an improvement on existing working conditions through their collective action. A trade union is thus an organization to which workers belong and which collectively deals with employers on behalf of the employees (Kelly, 1998; Visser, 1991; Kolagbodi, 1995; Adewumi, 1997; Fajana, 2000). The Trade Union Act (1973) defines a trade union as:

Any combination of workers or employees whether temporary or permanent, the purpose of which is to regulate the terms and conditions of employment of workers, whether the combination by any reason of its purposes being in restraint of trade and whether its purposes do or do not include the provision of benefits for its members. 
Trade unions therefore attempt to improve the terms and conditions of employment of their members by the employer through the process of collective bargaining. The unions' functions range from "economic, political, social welfare, psychological benefits and the opportunity to participate in managerial functions in the industry" (Fajana, 2000). The relevance of trade unions, apart from providing support for their members,has furtherbeen located intheir roles in addressing some of the deep-rooted inequalities in the society. Ebbinghaus and Visser (2000) opine that trade unions have transformed from "social self-help associations, mere bargaining agents or just lobbyists" and are now part of a social movement through which the working class has entered and promoted mass democracy. This is further established by the fact that trade unions are now among the largest and most influential special interest groups in democratic societies. This is more so that they play crucial roles in the election and selection of workers representatives in many companies in Europe, (Rogers and Streeck, 1995). According to the WorldLabourReport (1997-1998):

\footnotetext{
Unions play important role in guiding and upholding democracy and as defenders of social justice, in particular, by encompassing women, minorities, consumer groups, the unemployed and the growing ranks of working poor in the sphere of action (ILO, 1998).
}

Trade unions have been in the forefront of the yearnings for industrial democracy, otherwise, known as workers participation in the management of their enterprise. According to Fashoyin (1984b), industrial democracy ranges from "a means of workers control in which every worker becomes a partner both in respect of ownership and management of the company", to "a means of achieving effective utilization of the enterprises, human resources, since workers' participation in decision making is seen to enhance efficiency". For the UNDP (1993), industrial democracy means that workers are closely involved in the economic, social, cultural and political processes that affect their lives. Marshall (1997) has identified the attributes of participatory democracy as leadership succession, decision-making process and checks and balances.Fashoyin(1984b) notes that participatory democracy at the enterprise level enhances employee's productivity. If industrial democracy is desirable in the work place, it is logical that it should be extended to the trade union organization.It is the extent to which trade unions have conformed to the attributes of democracy in their internal organization that has prompted this study.

\section{Research Questions}

On the basis of the aforementioned issues, the following research questions are germane.

i. $\quad$ Are trade unions in Nigeria committedto the tenets of participatory democracy?

ii. Is participatory democracy desirable in trade unions?

iii. What type of commitment do they have towards internal democracy?

iv. How can trade unions be made to be more committed to internal democracy?

\section{Objectives of the Study}

The general objective of this study is to examine Nigerian trade unions' position on internal democracy. The specific objectives are to:

i. Examine the commitment of trade unions in Nigeria to the concept of internal democracy.

ii. To assess possible hindrances to the commitment to internal democracy by trade unions.

iii. To suggest ways of enhancing trade union commitment to internal democracy.

\section{Brief Literature Review}

A trade union is any organization of employees established to improve the conditions of employment of its members through the process of collective bargaining. Trade unionism arose from the assumption of workers' belief that they can benefits more through membership in a union than by doing it alone. This follows from the position that workers as individuals often feel powerless and unable to protect themselves against the unfair or exploitative exercise of employer authority.

Trade unions have grown in relevance over the years especially in the light of the belief that a healthy, independent labour movement is essential to democracy, (Godard 2003). Furthermore, there is a growing international recognition of the right to freely associate in unions and to engage in collective bargaining as a fundamental human right. 
This was affirmed by the International Labour Organization (ILO), in 1995 and the World Trade Organization (WTO), in 1996 (Godard, 2003). In essence trade unions are empowered to serve and negotiate collectively on behalf of their individual members. In exercising this relational power, the main weapon has been the strike action. This weapon has been whittled down in recent period by the Nigerian state through inhibiting legislations, (for example see Trade Disputes Act 1976 and Trade Disputes Act, 2004).

The strike weapon has been further blunted by the new structure of production whereby transnational corporations (TNCs) no longer depend on one factory and one workforce for production (Sklair, 1995). In addition, the new international division oflabour has become more flexible such that capital migrate in search of cheap labour while preventing labour from holding capital to ransom through a strike action. This new production process has considerably reduced union power to organize locally.Trade unions continue to face various challenges which are posing a threat to its ability to organize and serve their members. Globalization has led to job losses, reduced hours of work, and increased work load in the workforce. New work structures and settings inimical to trade union activities have thus emerged, such as casualization of employment, part-time work, out-contracting, employing women to replace men but paid lower wages, non-payment of wages and non-remittance of check-off dues.

The implications of this transformation (globalization) otherwise known as "postmodernism (Oechslin, 1997; Kelly, 1998), are:

i) a decline in trade union membership, density and influence.

ii) absolute or relative decline in numbers of male, manual, full-time industrial workers and the use of female, non-manual part-time and service workers.

iii) a decline in trade union movement as a unified political actor.

In the face of these challenges, trade unions need to be strengthened and empowered in order to counteract forces that are barriers to democracy and development. It therefore behoves trade unions to emphasize the entrenchment of industrial democracy in the enterprises. This is seen as the participation of workers in decisions within enterprises which enables a comparison of the influence of workers on the preparation, making and follow-up of decisions taken at the enterprise level.

The UNDP (1993) sees industrial (participatory) democracy as an essential element of human development. Shadare (2009) also states that the democratic management style is a veritable tool in the resolution of conflicts in the workplace. Consequently workers have shown their interest in participating in the decision making process in their organisations (Noah, 2008; Anya, undated). However, in Nigeria, the practice of workplace participatory democracy has been limited (Fashoyin, 1984a). This is due to:

a) centralization of decision-making process in many organizations;

b) employee's limited perception of the scope of participation due to ignorance or unwillingness of management to share decision-making roles;

c) fear of co-optation/integration into management;

d) government rules sometimes hinder participation;

e) The multi-national corporations are themselves controlled from the home bases.

Fatunde (2011) also posits that Nigerian governments do not subscribe to the tenets of industrial democracy as they unilaterally abrogate collective agreements freely entered into with labour. This is in addition to the fact that this was the period of military rule in Nigeria when all democratic principles were stifled. A greater challenge is the non-institution of internal democracy in Nigeria unions due to the unwillingness of their leaders to acknowledge basic constitutional requirements such as respect for individual rights and to be accountable to their members (Fashoyin,1984b). The place of union democracy cannot be overemphasized because any organization which is supposed to provide workers with democratic rights and protection in the workplace should itself provide such rights and protection internally (Godard, 2003).

\section{Conceptual Framework}

\subsection{Pluralist Perspective}

Pluralism had developed in western democracies with the aim of explaining the nature and distribution of power in those societies. Its central position is that power is distributed among various groups in society. This is based on the assumption that the organization is composed of individuals who constitute distinct sectional groups, each with its own interests, objectives and leadership (Ratnam, 2007). This leads to a complex of tenuous and competing claims which have to be 
managed in the interest of maintaining a viable collaborative structure.

As opposed to the unitary perspective, the pluralists see conflicts between management and employees as rational and inevitable. Common interest and mutual dependence are seen to be a necessary condition for the survival of the whole of which they are parts. According to Haralambos and Holborn (2000), pluralism's starting point is that industrial society increasingly differentiated into a variety of social groups and sectional interests. For example, the industrial revolution culminated into the division of labour and the subsequent growth in occupational groups. Each of the groups then developed its own needs and interests. Organizations were thereafter formed to represent and articulate these interests. These organizations thereafter became specialized and function as interest groups. Pluralism is therefore politics of interest groups with each pressing for its own advantage. As no one group is seen as being dominant, politics therefore becomes that of bargaining and compromise (Haralambos and Holborn, 2000). Such interest groups involved in bargaining and compromise are trade unions as well as professional associations.

As trade unions are the major groups that represent the interest of employees in any work organization, they have been able to use the ideology of pluralism to integrate the working class into the capitalist society. This is so because conflict between employers and employees has been institutionalized and regulated. This in turn has led to industrial stability as the relationship between capital and labour has moved from adversarial to the level of cooperation as either strives for its own survival. According to Dahrendorf, (1959) both sides are expected to gain from opportunity of pluralism (cited in Haralambos and Holborn, 2000). This he believes would lead to a more equal balance of power, between both employers and employees and the consequent development of what he calls industrial democracy.

For Dahrendorf (1959) the formation of workers' interest groups, that is, trade unions, signals the beginning of democracy in industry, and the groups are expected to represent workers. This is moreso that employers cannot bargain with a disorganized collection of employees. However to be effective, the interest groups require legitimization of employers and the state. The recognition symbolizes a major step towards industrial democracy and the institutionalization of industrial conflict. There is no doubt that trade unions have been effective in making possible the provision of economic benefits and rights for their members. This is because they are responsible for increase in earnings, improvement in working conditions, longer and paid holidays and shorter working week, among several others.

However pluralism has been criticized for issuing what Dahl and Rose (cited in Haralambos and Holborn, 2000) call non-decision making. That is the possibility that some are able to prevent certain issues being decided upon. It is obvious that trade unions would not support decisions that could alter the structure of inequality. For instance women participation in the rank-and-file of trade unions belies their population. Healy and Kirton (2000) have also noted the enforcement of oligarchic structure in trade unions. This has encouraged the struggle to access power resources. They note that this conflicts with their democratic function of representing their membership.Another criticism of the pluralist perspective is that it assumes that the electorate is adequately represented if its opinions are reflected in government activities. Within the trade unions officials tend to convert the union machinery for personal aggrandizement while trading away the union.

\section{Research Methods}

This study is about internal governance within trade unions in Nigeria. Six hundred and forty members of five trade unions were selected through a probability, multi-stage random sampling technique. The five unions chosen for the study are the Nigerian Union of Teachers (NUT), the Nigerian Union of Journalists (NUJ), the National Association of Nurses and Midwives of Nigeria (NANMN), the Nigerian Union of Civil Service Secretarial and Stenographic Workers (NUCSSSW), and the National Union of Food, Beverage and Tobacco Employees (NUFBTE). These unions are among the twenty-nine (29) industrial unions that emerged as a result if the restructuring excercise of trade unions and as listed in the Trade Unions (Amendment) Act. 1996. The sampled unions fall into different sectors of the Nigerian economy. For this study, the twenty-nine (29) industrial unions were grouped into five (5) sectors with related occupational/services, viz, Educational, Health/Medical, Public Service, Mass Communication and Economic/Transport. From each group, a random selection of one industrial union was done leading to the selection of the five (5) unions that served as case studies for the research. To elicit data from the selected respondents, both qualitative and quantitative methods were used.

For the qualitative data, in-depth interviews were conducted in order to understand deeper meanings of the questions in the questionnaire. On the other hand, for the quantitative data gathering, a questionnaire containing openand close-end questions was utilized. A total number of fifteen (15) members of each of the five trade unions were selected for the in-depth interview. Both qualitative and quantitative data were analyzed accordingly. Copies of the questionnaire were analysed through the StatisticalPackage for SocialSciences (SPSS) software while data from the in- 
depth interviews were analysed thorough content analysis and quoted verbatim where required to support data from the questionnaire.

\section{Discussion of Findings}

Series of questions were posed to respondents in order to assess their opinions on the level of their involvement in the internal administration of their trade unions. The data show that about 80percent of the respondents claim to belong to one trade union or the other. This is understood within the context of the fact that wage employment is a neccesary condition for trade union membership. Besides, under theTrade Union Act, membership of trade unions is made open and assumed to be mandatory except one opts out. On the issue of 'active membership', about 80 percent of respondents also assert that they are active. This is based on the claim that they attend meetings regularly and also pay their dues. Very few of the respondents occupied any positions in the unions (8percent).

On the levels of participation and involvement in the affairs of the unions, about 60percent of the respondents attend meetings. However, of this number, only about 44percent can be said to be deeply involved and therefore reflective of their confidence in the unions, by attending meetings. Equally significant is the number of respondents who claim not to attend meetings (41percent). These are, no doubt, passive members of the unions who don't see any need to be involved in their unions. These individuals are totally apathetic to their unions (Rush and Althoff, 1972), who but probably would have withdrawn their membership of the unions if it were convenient. For those that claim active participation, this is hinged on their claim that 'they attend meetings regularly' (511); 'pay dues' (598) and 'being an official' of the particular union.

Voting is regarded as the least active form of political participation (Rush and Althoff, 1972). This is because it requires a minimal commitment which more often than not, ceases once the vote is cast. Data from the study reveal that close to 63percent of the union members vote, as and when required. This is against 37percent of the members who don't vote. This set of people, nodoubt, appears to have completely lost interests in the union. That members of the unions don't attend meetings or vote at such meetings may be a reflection of the low frequency of meetings of the unions. About 60percent of the respondents claim that the unions 'seldomly' meet, while only 40percent claim that they meet 'regularly'. Perhaps if meetings are called regularly, attendance would improve.

In terms of seeking elective positions in the unions, 42percent of the respondents claim to have contested elections in the past. On the other hand, 58percent of them have not. One of the elements of democracy is the process of decision making, as it shows the broadness of opinions and ultimately the confidence in the outcome of the process. For a large majority of our respondents (33percent), it is 'the leaders' that take decisions in the unions. This corroborates Michel's thesis on the 'iron law of oligarchy' whereby those who wield power within an organisation are always a small minority. It also shows the back-stage role of the Congress of the unions in terms of decision making, as only 9percent agree that decisions of unions are taken at the 'meetings of all union members'. As many as 14percent actually claim ignorance of the process of decision making in the unions. This explains why only 31percent of respondents take part in the decision making process.

Women now constitute about28 percent of the labour force in Nigeria (NBS, 2009). Data recieved however indicate that the participation level of women in trade union activities is a mere 23percent. Respondents, during the indepth interview sessions, attributed this to some internal workings of the unions which they claim are not gender sensitive. Some of these are the timing and venues of meetings. According to them, union meetings are held late in the night and are usually held in hotels, a situation that is anti-thetical to our cultural values. These and some other patriarchal tendencies are said to account for the low women participation in union activities.

Another attribute of a democratic culture is the ability of members to get adequate feedback and information from their leaders. Besides, there must be regular consultations especially at the level of Congress. However, the available data indicate that members are oblivious of the way their unions are run. For example, on 'whether members are consulted before meetings with management', close to 40percent of the respondents assert that they are not consulted while 33percent agree that they do it but occassionally as only 28percent claim that they consult. Furthermore, on 'whether union leaders inform members of their activities', a similar trend is presented. That is, only 36percent of respondents agree that there is a feedback process while as many as 61percent of the respondents agree less. On a general note, respondents were asked to access their unions in relation to their performance over the years. Only 28percent agree that their performance was 'Excellent/Good', while for 24percent of them, the unions didn't perform well. 


\section{Conclusionand Recommendations}

The study focused on the trade unions in Nigeria and their disposition towards the concept of internal democracy. Trade unions are institutions that arose from the need for workers to have a say in the decision making process in their organisations. They are therefore, expected to be democratic especially in relation to the internal management of their affairs. It is however obvious from the data and other evidences from our respondents that trade unions in Nigeria are far from imbibing the ethos of democracy. This is reflected in the low participation in their affairs by their members. Apathy towards their activities are very high as reflected in the attendance at meetings, voting, bias towards women and general decision making process.

Given the challenges facing trade unions generally, especially in this era of globalisation and economic restructuring, it is imperative for trade unions to harness the resources of all its members in order to sustain its growth and development. As the statutory vehicle for the articulation and protection of the collective interests of workers, trade unions should enable all members to participate in all their activities. This will remove the general conception that they are patriarchal and oligarchical organisations, out to prevent general participation. Trade unions should therefore go beyond merely professing the ideals of democracy. They must demonstrate them practically by creating a level play ground for all members to take part in the decision making apparatus of the unions.

\section{Whether they belong to a Trade Union}

Yes

No

No Response

Total

Whether they are active members

Yes

No

No Response

Total

Whether they occupy a position in the Union

Yes

No

No Response

Total

How often they attend meetings

Very Often

Often

Seldom

Don't attend

Total

Level of participation in Union activities

Attend meetings regularly

Pay dues

Union executive member

Frequency of voting at Union meeting

Very Often

Often

Sometimes

Never

Total

Frequency of meetings of the Union

Very Often

Often

Seldom

Total

$\begin{array}{rc}498 & 77.8 \\ 93 & 14.5 \\ 49 & 7.7 \\ 640 & 100 \\ & \\ 511 & 79.8 \\ 102 & 16.0 \\ 27 & 4.2 \\ 640 & 100\end{array}$

50

7.8

84.4

7.8

100

50

640

18.7

25.0

15.6

40.7

100 
Whether they have contested an election

$\begin{array}{lll}\text { Yes } & 267 & 41.7 \\ \text { No } & 373 & 58.3 \\ \text { Total } & 640 & 100\end{array}$

How decisions are taken in the Union

Union leaders decide

212

Committees of Union

Meeting of all Union members

Combination of many

Don't know

14.6

Total

Involvement in the decision-making process

Yes

No

Total

\section{Performance of their Union leaders}

Excellent

Good

Poor

Total

Whether women participate actively in the Unions

$\begin{array}{lll}\text { Yes } & 494 & 77.1 \\ \text { NO } & 146 & 22.9 \\ \text { Total } & 640 & 100\end{array}$

Are members consulted before meetings with the management of your organisation

$\begin{array}{lrl}\text { Very Often } & 107 & 16.7 \\ \text { Often } & 75 & 11.7 \\ \text { Seldom } & 210 & 32.8 \\ \text { Not at all } & 248 & 38.8 \\ \text { Total } & 640 & 100\end{array}$

Whether Union leaders inform members of their activities

$\begin{array}{lll}\text { Very Often } & 108 & 16.8 \\ \text { Often } & 131 & 20.5 \\ \text { Seldom } & 204 & 31.8 \\ \text { Not at all } & 197 & 30.8 \\ \text { Total } & 640 & 100\end{array}$

\section{References}

Adewumi, F. (1997). "Responsiveness in Trade Unionism: The Challenge of the 21st Century" in,Trade Unionism in Nigeria: Challenges for the 21st Century. Adewumi, F. (ed) Lagos, Friedrick Ebert Foundation. Pp. 3-17.

Anya, K. A. (undated) Industrial Democracy and its Prospect in Nigeria: A Comparative Assessment. www. Nigerialawguru.com/articles/labourlaw. Retrieved 27/3/12

Chukwuemeka, E.E. O. and N. Chukwuemeka, (2012) A Pedagogical Analysis of Labour and Management Relations in Nigeria Local Government System: A Study of Enugu State. Agricultural Journal 7 (1): 42-52.

Ebbinghaus, B. and J. Visser(2000).The Societies of Europe: Trade Unions in Western Europe Since 1945. Basingstoke, Macmillan Reference Ltd.

Fajana, S. (2000).Industrial Relations in NigeriaTheory and Features; Lagos, Labofin and Co.

Fashoyin, T. (1984a). Internal Dynamics in Nigeria. Paper Series; Department of Industrial Relations and Personnel Management, Lagos, University of Lagos. 
Fashoyin T. (1984b). "Democracy in Industry: A Desirable Management Practice." A Paper Presented at a Meeting of the Rotary Club of FestacTown, Lagos, November.

Fatunde, T. (2011) Nigeria: Striking Academic Close Public Universities. www.Universityworldnews.com/article. Retrieved 23/01/12.

FRN.(1973). Trade Unions Act 1973, Lagos, Government Printer.

FRN.(1996). Trade Unions Act (Amendment) 1996: Lagos, Government Printer.

Godard, J. (2003)Industrial Relations, The Economy, and Society. Ontario, Canada.

Haralambos, M. and Holborn, A. (2000).Sociology; Themes and Perspective. London, Collins Publishers.

ILO.(1998). World Labour Report 1997-1998.Geneva, International Labour Organization.

Kelly, J. (1998). Rethinking Industrial Relations: Mobilization, Collectivism and Long Waves. London, Routledge.

Kolagbodi, E. (1995). Collected Speeches Vol. 1, M.E. Memorial Foundation, Ikeja, Malthouse Press Ltd.

Marshall, J. (1997). "Globalization from Below: The Trade Union Connections". Globalization, Adult Education and Training: Impacts and Issues. Walters, S. (ed) London, Zed Books Pp. 51-68.

NBS,(2009) Social Statistics in Nigeria. Abuja. Federal Republic of Nigeria

Noah, Y. (2008) A Study of Worker Participation in Management Decision Making within selected Establishments in Lagos, Nigeria. J. Soc. Sci., 17(1): 31-39

Oechslin, J. (1997). The Effective Employer in the 21st Century: A Global Perspective: Management in Nigeria. Vol. 2, April-June, Pp. 58-67.

Ratnam, V.C.S. (2007). Industrial Relations.New Delhi, OxfordUniversity Press.

Rogers, J. and W. Streck.(1995). Works Councils:Consultation, Representation and Cooperation in Industrial Relations, Chicago, University of Chicago Press.Visser, J. 1991. "Trends in Trade Union Membership" Employment Outlook 1991. Paris, OECD, Pp. 97-143.

Rush, M. and P. Althoff. (1972). An Introduction to Political Sociology. Melbourne, Thomas Nelson Ltd.

Shadare, O. A. (2009) Influence of Management Style on Conflict Resolution Effectiveness in Work Organisations in South-Western Nigeria. African Journal of Education and Developmental Studies. Vol. 6. No. L. Sept.

Sklair, L. (1995). "Social Movement and Global Capitalism", Sociology, 29: 3 11-17.

UNDP. 1993. Human Development Report 1993: New York, UNDP.

Visser, J. (1991). "Trends in Trade Union Membership",Employment Outlook 1991. Paris, OECD, Pp. 97-143.

Zysman J. and A. Schwartz.(1998)Enlarging Europe: The Industrial Foundation of a New Political Reality. Berkeley, University of California. 